\title{
ANALISIS DAN PENERAPAN KURIKULUM HIGHER ORDER PADA PELATIHAN DASAR DASAR PEKERTI AKADEMI PARIWISATA CBI SUKABUMI
}

\author{
Rafdi $^{1}$, Yulianti $^{2}$ \\ 1,2Akademi Pariwisata CBI Sukabumi \\ ${ }^{1}$ rafdi@gmail.com \\ 2yulianti@gmail.com
}

\begin{abstract}
The training held by the CBI Tourism Academy was able to formulate a curriculum that was used as a benchmark for the Higher Order for the three taxonomies referring to theoretical-based analysis. then applied during training according to a structured procedure which is arranged according to consecutive steps. is understanding Higher Order taxonomy, understanding integration and examples of Higher Order implementation, understanding the competency composition of Higher Order and the appropriate learning methods, until finally the assessment, describing the accumulated assessment to find goals, namely learning that isproduce: output, outcomes, and impact. Training objectives so that the training participants have the ability to transfer to students the abilities that are mastered from the results of the training. The basic assumption about the Higher Order ability target actually boils down to students.This goal is in tune and at the same time is the target of MBKM, namely learning that produces results so that the learning outcomes of graduates are able to compete in an international locus The results of observations and documentation from the qualitative descriptive research method applied to this research method show the substantive framework of the material presented, the processes and stages carried out to manifest into an integral training qualification
\end{abstract}

Keywords: Learning that results through the application of Higher Order competencie.

Abstrak - Pelatihan yang diadakan oleh Akademi Pariwisata CBI mampu merumuskan kurikulum yang digunakan sebagai patokan bagi Orde Tinggi untuk ketiga taksonomi yang mengacu pada analisis berbasis teori. kemudian diterapkan selama pelatihan menurut prosedur terstruktur yang disusun menurut langkahlangkah berurutan. adalah memahami taksonomi Orde Tinggi, memahami integrasi dan contoh implementasi Orde Tinggi, memahami komposisi kompetensi Orde Tinggi dan metode pembelajaran yang sesuai, hingga akhirnya penilaian, mendeskripsikan akumulasi penilaian untuk menemukan tujuan, yaitu pembelajaran yang menghasilkan: output, outcome, dan dampak. Tujuan pelatihan agar peserta pelatihan memiliki kemampuan untuk mentransfer kepada siswa kemampuan yang dikuasai dari hasil pelatihan. Asumsi dasar tentang target kemampuan Orde Tinggi sebenarnya bermuara pada siswa. Tujuan ini selaras dan sekaligus menjadi target MBKM, yaitu pembelajaran yang menghasilkan hasil sehingga hasil belajar lulusan mampu bersaing di kancah internasional. lokus Hasil observasi dan dokumentasi dari metode penelitian deskriptif kualitatif yang diterapkan pada metode penelitian ini menunjukkan kerangka substantif materi yang disampaikan, proses dan tahapan yang dilakukan untuk mewujudkan menjadi suatu kualifikasi pelatihan yang integral

Kata Kunci : Pembelajaran yang menghasilkan melalui penerapan kompetensi Higher Order.

\section{PENDAHULUAN}

Teori Bloom merujuk ke pada kepentingan pengembangan metode pembelajaran melalui paradigma taxonomy tiga potensi itu berstrata dari dasar sampai ke puncak. Dengan kata lain membuat ukuran bertahap dari kemampuan yang paling dasar sampai tertinggi. Kemampuan dasar berfikir/cognitive, bersikap/affective, mengaplikasikan gerak/psychomotor sampai ke tingkat yang paling tinggi. 
Tingkat paling tinggi untuk cognitive diramu dalam satu konteks yang disebut dengan Higher Order Thinking Skill (Hots). Tingkat dasar atau rendah diramu dalam satu konteks disebut Lower Order Thinking Skill.

Saat ini banyak mendapat sorotan dan kajian tentang berpikir tingkat tinggi atau Hots sampai di analogi dan di komperatif terhadap kemampuan mesin berteknologi tinggi. Berpikir tingkat tinggi merupakan potensi yang dimiliki manusia dan tidak dimiliki oleh mesin buatannya. Berpikir tingkat tinggi bukanlah tiruan sebagaimana kemampuan mesin menirukan apa yang dicontohkan melalui transfer software.

Dari sinilah perspektif pembeda yang tegas terhadap kemampuan manusia dengan mesin, adalah tentang rasa ,tentang daya urai, tentang kreatif, tentang inovatif yang hanya dimiliki oleh manusia.

Bila berfikir tingkat tinggi banyak mendapat sorotan dan dijadikan standar segala sesuatu yang bersifat deskripsi capaian tingkat atas untuk outcome pembelajaran maka bagaimana pula terhadap Affective dan Psicomotor? Untuk keselarasan layaklah ketiganya disama stratakan hingga disebut dengan Higher Order/H.O. Untuk memahami Higher Order mulai dari tangga berapa sampai ke berapa terhadap Cognitive atau diistilahkan dengan Hots, terhadap Affective, terhadap Psikomotor merupakan salah satu unsur penting yang akan dipaparkan dalam pembahasan penelitian ini.

Wajah pendidikan kita secara generalisasi, termasuk di perguruan tinggi, sudah cukup lama berbandrol Lower Order/LO yakni berbasis tingkat rendah. Dan bandrol itu akan segera dicabut dan diganti melalui penerapan
Higher Order. Pembelajaran Higher Order merupakan suatu sistem yang integral melalui berbagai ramuan yang berkontribusi sebagai sub sistem, baik secara langsung maupun tidak langsung seperti sosialisasi dan penajaman konsep creative thinking, critical thinking, collaborative, (Higher order thinking skills refers to the mental process of analysis, synthesis and evaluation, and is commonly used in activities such as problem solving, reasoning, thinking, assessing, and concluding( (Bloom, 1956). Regulasi di bidang pendidikankan pun cukup kuat memberi andil melalui konsep MBKM.

\section{A. Ciri Ciri Higher Order}

1. Berfokus ke pada action dan hasil.

2. Lingkaran yang tidak pernah putus. Hal ini disebabkan rasa ingin tahu dan berkreasi manusia tidak berhenti pada satu capaian tertentu.

3. Peningkatan kemampuan berbanding lurus dengan bentuk, metode, serta pengalaman belajar.

4. Bentuk pembelajaran praktek an praktikum, dan sejenisnya

\section{B. Kesikapan Penghalang Higher} Order.

1. Takut salah untuk mengekspor ideide

2. Terlalu tekstual

3. Mengutamakan simbol-simbol dibanding kompetensi

4. Terbiasa dengan jalan pintas

5. Cepat puas

6. Miskinnya pengalaman lapangan

7. Terlalu praktis hingga jauh dari kaidah-kaidah dan jalur akademis

8. Fanatisme terhadap teori tertentu

\section{Kesikapan untuk Mencapai Higher Order \\ 1. Memiliki orientasi Pembelajaran ber outcome}


2. Haus akan berbagai pengembangan bentuk dan metode pembelajaran

3. Gemar beranalisis

4. Membiasakan kinerja yang terukur.

Desain untuk kerangka pembelajaran Higher Order di Perguruan Tinggi akan tergiring dengan sendirinya ke goals: Output, Outcome, bahkan Impact, asalkan tersusun sistematis, terukur, dikembangkan dengan baik, dan menyertakan unsur-unsur yang diperlukan sehingga tumbuh keterampilan berpikir/kecerdasan pada perguruan Tinggi tersebut, (According to King, 1997: the ability of higher order thinking skills are activated when individual encounter unfamiliar problems, uncertainties, questions or dilemmas. When the skills are nurtured and well developed, one can perform better during explanation and making decisions as well as grow their intellectual skills). Obyek penerapan Higher Order tidak hanya terfokus ke pada mata kuliah tetapi juga bisa diaplikasikan ke pada pokok bahasan dan sub pokok bahasan. Dalam penelitian ini dipaparkan berbagai unsur terkait membentuk satu kesatuan yang integral untuk memenuhi pencirian kerangka pembelajaran Higher Order.

Seiring penerapan konsep MBKM maka Akademi Pariwisata CBI Sukabumi punya inisiatif mengadakan pelatihan dasar-dasar Pekerti (Program Peningkatan Keterampilan Dasar Teknik Instruksional ) bagi dosen dengan prioritas materi adalah pembelajaran Higher Order. Tujuan dan manfaatnya adalah supaya dosen menerapkan materi ini terhadap mahasiswa.

Analisis pada penelitian ini adalah tentang apa dan bagaimana pengolahan kurikulum Higher Order serta proses aplikasinya dalam pelatihan yang diselenggarakan Akademi Pariwisata CBI. Jadi ada dua titik fokus yang dianalisis, yakni kajian kurikulum dan proses pelaksanaannya. Lama pelatihan pada setiap gelombang bervariasi. Namun rentang waktu minimal adalah selama tiga hari per gelombang. Pelatihan ini telah dilakukan sebanyak enam gelombang selama tahun 2020.

\section{METODE PENELITIAN}

\section{A. Desain Penelitian}

Desain penelitian yang diterapkan adalah deskriptif kualitatif yakni mendeskripsikan fenomena-fenomena yang terkait dengan metode dan proses pelatihan dasar-dasar Pekerti berbasis Higher Order diselenggarakan oleh Akademi Citra Buana Indonesia. Dalam hal ini titik fokusnya adalah terhadap kurikulum pelatihan.

Penelitian deskriptif adalah penelitian status kelompok manusia, suatu subjek, suatu set kondisi, suatu sistem pemikiran ataupun kelas peristiwa masa sekarang (Nazir,dari Anugerah Ayu Sundari : 2018).

Begitu banyak tujuan penelitian deskriptif. Yang berkenaan dengan penelitian ini adalah bahwa penelitian deskriptif ditujukan untuk mengetahui seperangkat kategori dan klarifikasi subjek penelitian, mengetahui seperangkat tahapan atau proses.

\section{B. Analisis Data}

Analisis data kualitatif yaitu dengan cara mengorganisir data, memilah data, menemukan pola, dan menemukan apa yang paling penting. Dalam penelitian ini dilakukan dengan analisis pola kurikulum 
pelatihan, kemudian memilahnya hingga ditemukan apa yang paling penting.

\section{Teknik Pengumpulan Data}

Teknik pengumpulan data dilakukan dengan observasi, yakni terjun langsung pada saat pelatihan mengamati proses dan kurikulum pelatihan . Selain itu digunakan juga teknik pengumpulan dokumentasi yang meliputi menginventaris dokumen makalah pelatihan, lembaran tugas pelatihan, dan lain lain.

\section{Populasi dan Sasaran Penelitian}

Populasi dalam penelitian ini adalah peserta pelatihan yang semuanya berprofesi sebagai dosen, namun sasaran utama penelitian ini adalah kurikulum pelatihan.

\section{E. Approach Sasaran Penelitian}

Pendekatan penelitian dilakukan dengan analisis materi kurikulum, metode dan dasar berpikir kurikulum, dan proses pelaksanaan pelatihannya.

\section{HASIL DAN PEMBAHASAN}

Analisis secara general dari hasil penelitian menunjukkan kedalaman materi pelatihan, komperatif antar sub bahasan, serta mekanisme proses untuk mencapai goals pelatihan yakni Learning Outcome. Kedalaman dan komperatif hasil penelitian dicirikan melalui kupasan terhadap Higher Order Thinkking Skill yang dianalisis secara tajam kemudian dikomperatif sekaligus untuk disetarakan dengan Affective dan Psyschomotor yang menghasilkan konteks terhadap keduanya yang masing maisng disebut Higher Order (H.O). Selanjutnya, dijabarkan penerapan kombinasi materi pelatihan dan proses pelatihan yang dilaksanakan menurut struktur dan mekanismenya .

\section{Langkah Pertama : Memahami Hots dan H.O}

Untuk langkah pertama ini peserta pelatihan harus terlebih dahulu memahami apa itu Hots dan H.O sekaligus tujuannya.

\section{HOTS (C) :}

Bagaimana supaya mahasiswa bernalar tingkat tinggi dalam hal mengidentifikasi dan memecahkan masalah .

Bagaimana supaya mahasiswa bernalar tingkat tinggi untuk menghasilkan karya yang kreatif dan inovatif.

\section{H.O (A) :}

Bagaimana supaya mahasiswa mampu memenage nilai -nilai. Bagaimana supaya mahasiswa punya nilai - nilai yang kokoh yang tertanam dalam dirinya.

\section{H.O (P) :}

Bagaimana supaya mahasiswa mampu berkinerja secara kreatif. Bagaimana supaya mahasiswa mampu berkreasi dalam membuat produk. Bagaimana supaya mahasiswa mampu mahir dalam mengerjakan sesuatu Berdasarkan Hots ( C ) merupakan kemampuan berfikir tingkat tinggi, pembeda yang tegas terhadap kemampuan manusia dengan mesin. Berfikir tingkat tinggi adalah cara untuk menguji apakah seseorang mampu menganalisis ,membandingkan, menghitung, dan sebagainya. Jadi memang diperlukan kemampuan yang tidak biasa (Prof. Intan Ahmad, Ph.D : 2018 ) 


\section{Langkah Ke dua : Memahami Integrasi Hots /H.O dan Penerapannya}

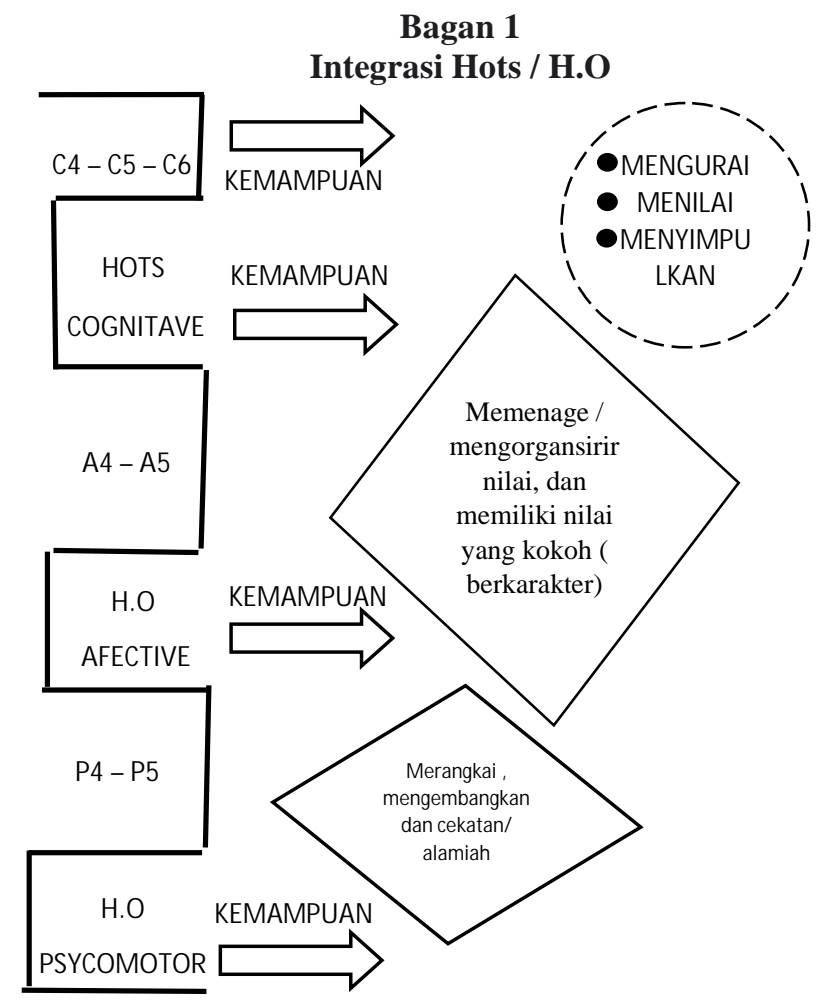

Mengurai / Deduksi C4 :

Kupaslah secara mendalam hingga ditemukan item-item / detail-detailnya, kalau diperlukan cari hubungan antar item-item tersebut, bila diperlukan lagi organisasikan / kelompokkan item-item yang saling berhubungan.

Catatan : dalam mengurai, bilamana hasil uraian itu diambil dari hasil yang sudah diuraikan oleh orang lain, maka itu bukanlah mengurai.

\section{Menilai C5 : Langkah-langkah dalam menilai}

Langkah pertama, memberi nilai baik secara kualitas maupun kuantitas. Langkah kedua, menambah atau mengurangi nilai baik secara kualitas maupun kuantitas.

\section{Contoh-contoh padanan kata nilai secara} kualitas.:

Dominan ; yang dominan, yang kurang dominan, yang tidak dominan

Pengaruh ; yang berpengaruh, yang kurang berpengaruh, tidak berpengaruh Penting ; yang penting, yang kurang penting, tidak penting

Banyak ; yang banyak, yang kurang banyak, tidak ada

Bagus ; yang bagus, yang kurang bagus, tidak bagus

Unik ; yang unik, yang kurang unik, tidak unik

Baik ; yang baik, yang kurang baik, tidak baik

Puas ; memuaskan, kurang memuaskan, tidak memuaskan

Hubungan ; yang berhubungan, tidak kuat hubungan, tidak berhubungan

Ciri ; berciri, kurang berciri, tidak berciri Menggabungkan / menyimpulkan / induksi C6 :

Menggabungkan yang telah diurai tanpa merubah bobot bukanlah kreasi / inovasi, jadi yang dimaksud kreasi dan inovasi adalah bilamana hasil uraian yang digabungkan kembali terjadi penambahan atau pengurangan nilai, baik secara kualitas dan atau secara kwantitas. Catatan : karya kreasi adalah yang daya ciptanya lebih tinggi dari inovasi. Sedangkan inovasi adalah lebih kepada perubahan nilai yang parsial. Bahasa lain untuk inovasi adalah memodifikasi.

\section{Contoh penerapan $\mathbf{C 4 + C 5 + C 6}$ :}

Sebuah objek yang dikupas / diurai, kemudian diberi bobot, menambahkan kualitas atau kuantitas, mengurangi kualitas atau kuantitas, lalu di induksi / disimpulkan sehingga menghasilkan nilai 
baru, yakni menjadi hasil karya yang kreatif dan inovatif. Proses ini berjalan terus menerus berulang dalam bentik circle. Hal ini disebabkan bahwa karya yang saat ini dianggap sesuatu yang kreatif / inovatif maka dimasa mendatang dianggap karya biasa.

\section{Memanage Nilai A4 + Berkarakter A5 :}

Mampu memenage nilai ataupun mengorganisir nilai, kemampuan selanjutnya adalah tertanam dalam diri nilai-nilai yang kokoh yang ciri-cirinya adakalanya bisa diamati secara observasi yang menandakannya sebagai karakter.

Memanage Skill P4 + Natural P5 :Dalam mengerjakan sesuatu mampu mengembangkan, memodifikasi, merangkai, kemampuan selanjutnya adalah cepat /cekatan / alamiah, hingga bisa meningkatkan jumlah produksi.

\section{Contoh Penerapan HOTS/H.O}

Seorang Dokter melakukan pembelajaran dalam bentuk praktek untuk mampu menganalisis sistem pencernaan pada manusia. (C4,A4,P5). Dokter tersebut melakukan operasi tubuh manusia dan dia pun memilah hasil operasi tersebut berdasarkan item - item yang terdiri dari 1). Hati, 2). Jantung, 3). Paru - paru, 4). Lambung, 5). Usus halus, 6). Anus, 7). Dan lain lain. (C4/mengurai menjadi item, A4,P4). Lalu Dokter tersebut menemukan pula bahwa ada hubungan saling terkait terhadap pencernaan meliputi 4, 5, 6. (C4/menghubungkan antara item - item A4,P4). Kemudian Dokter tersebut mengorganisir 4, 5, 6 menjadi satu kesatuan yang disebut sebagai sistem pencernaan dalam tubuh manusia. (C4/mengorganisasi, A4,P4). Dokter tersebut menemukan pula bahwa ada bagian dari 5, yakni usus buntu yang tingkat vitalnya di bawah item - item lainnya. (C5/membobot, A4,P4). Dia memeriksa usus buntu yang kebetulan dia melihat ada gangguan sehingga usus buntu itu dai potong. (C5, A4,P4). Setelah itu Dokter tersebut menjahit / menyatukan kembali tubuh yang telah dia operasi. (C6, A4, P4).

\section{Langkah Ke Tiga : Memahami Komposisi Kompetensi dan Metode Pembelajaran}

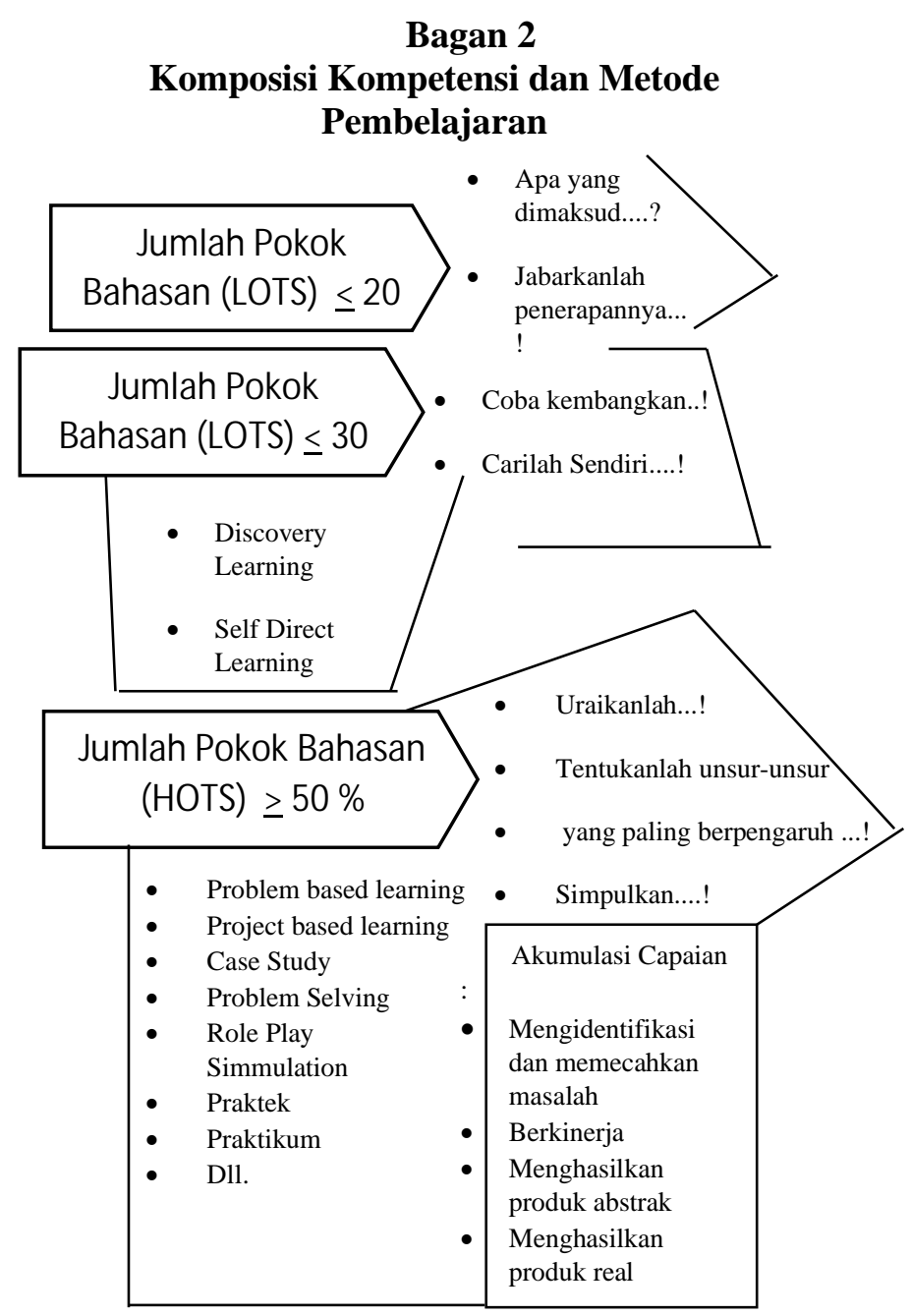

Dari gambar di atas memperlihatkan komposisi kompetensi secara bertingkat. Bilamana pembelajaran dilakukan selama 
satu semester maka persentase pembelajaran Lots ( Lower Order Thinkking Skill) dikategorikan dua macam. Pertama, yang berbobot dua puluh persen bisa dilakukan melalui metode perkuliahan tatap muka. Kemudian Lots yang tiga pulih persen dilakukan dengan metode pembelajaran kemandirian. Discovery Learning dan Self Directed menuntut mahasiswa punya upaya yang kuat untuk mandiri dalam pembelajaran.

Langkah ini menjadi penting sebagai wujud pengalaman belajar untuk modal ke langkah selanjutnya, yakni menuju Hots. Ke dua metode pembelajaran ini identik dengan warming up sebelum sampai ke tingkat yang lebih sulit yaitu Hots.Korelasi kemampuan kemandirian untuk mecapai Hots sangat jelas. Artinya bahwa Hots yang identik dengan bernalar akan sulit dicapai bilamana masih mengandalkan bimbingan dan arahan.

Komposisi Hots yang totalnya lima puluh persen memberi pemahaman bahwa asumsi dasar tentang kuliah praktek/praktikum dan sejenisnya minimal enam puluh persen. Bahwa pembelajaran Hots itu identik dengan praktek/praktum seperti problem based learning, project learning, dan lain lain.

Sebagaimana dijabarkan pada gambar di atas ada perbedaan makna antara kalimat Lots dengan Hots. Semua kalimat perintah pada Lots tidak ada yang berkonotasi sebagai analisi, sementara kalimat seru pada Hots tingkat terendahnya adalah kalimat seru untuk menganalisis. Sehingga pada akhirnya Hots itu merupakan akumulasi pembelajaran yang menghasilkan. Dari gambar di atas bisa dilihat ada empat macam hasil dari akumulasi pembelajaran Hots.

\section{Langkah Ke Empat : Assesment dan Goal}
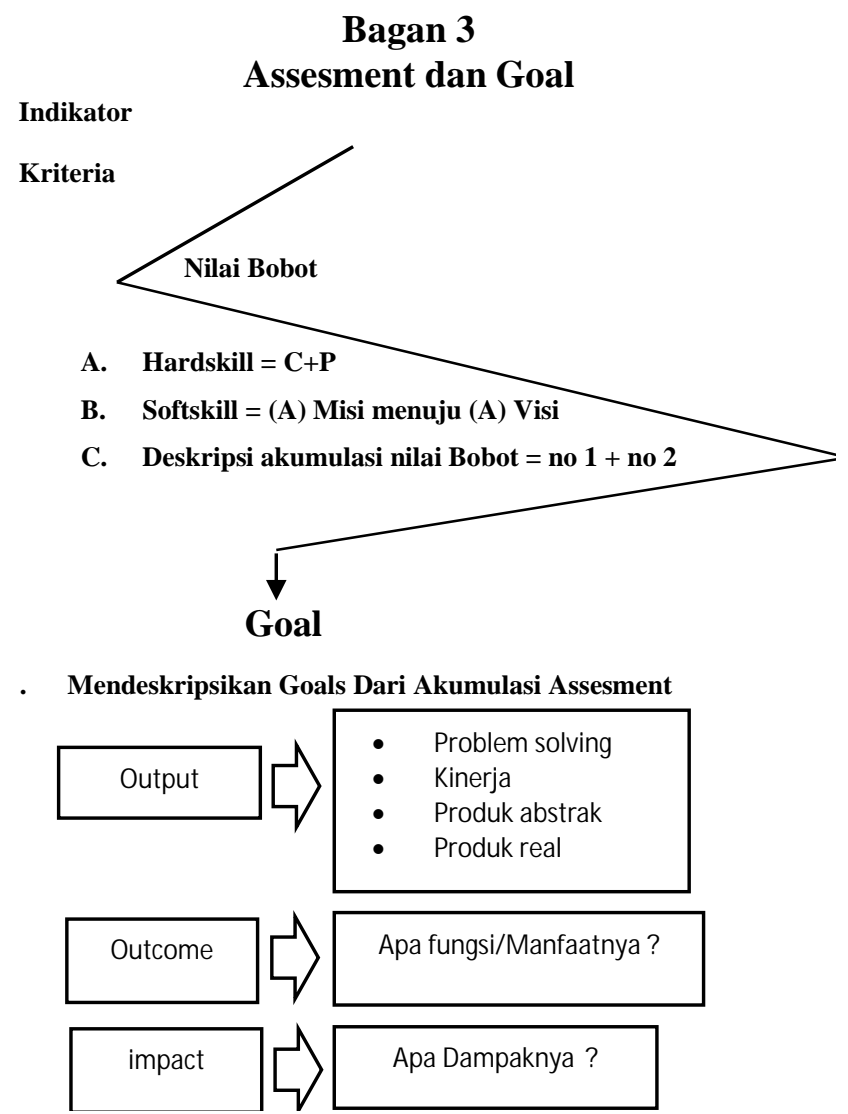

Proses untuk mencapai hasil sebagaimana termaktub pada Langkah Ke Tiga haruslah terlebih dahulu melalui assesmen. Pada Langkah Ke Empat ini, sebagaimana alur yang terlihat pada maps, proses assesmen dilakukan dengan cara meng assesmen indikator dan kriteria pembelajaran yang bisa dilakukan dengan rubrik analitik. Rubrik adalah alat skoring untuk assesmen yang bersifat subjektif yang di dalamnya terdapat satu set kriteria dan standar yang berhubungan dengan tujuan pembelajaran yang akan diakses ke peserta pembelajaran (Bernie Dodge dan Nancy Pickett, dalam Samhis Setiawan,2021).

Indikator dan kriteria yang di assesmen secara rublik analitik merupakan 
bahagian bahagian dari materi pembelajaran yang sudah dipilah pilah sesuai kebutuhan atau berdasarkan pokok pikiran atas pemilahan tersebut. Pokok pikiran untuk pemilahan dalam Higher Order mengacu pada dua hal secara umum. Pertama, assesmen kompetensi terhadap gabungan Cognitave dengan Psychomotor untuk assesmen hard skill,ke dua, mengassesmen kompetensi Affective untuk assesmen soft skill.

Soft skill terdiri dari nilai misi yang di ass eesmen secara rubrik yang berpedoman atau mengarah ke pada nilai visi yang dirumuskan. Untuk menghasilkan assesmen yang lebih bermutu maka semakin terurai unsur unsur kompetency yang dinilai akan semakin akurat.

Akumulasi assesmen hard skill dan soft skill merupakan nilai final. Karena nilai final ini masih berbentuk nilai bobot maka perlu di transfer ke nilai mutu. Nilai mutu itu perlu dideskripsikan dalam paparan kalimat. Misal nilai B, perlu dipaparkan bahwa capaian B itu apa dan bagaimana kaitannya terhadap capaian.

Goals merupakan jenis/noun dan tingkat kompetensi capaiannya. Adalah output, outcomes,impact terhadap problem solving (Cognitave majority), atau kinerja (Psychomotor majority),atau produk abstrak ( Cognitave majority), atau produk real ( Psychomotor majority ). Pengertian majority di sini merupakan takaran jenis kompetensi yang mendominasi yang disimpulkan berdasarkan hasil akumulasi assesmen.

\section{KESIMPULAN}

A. Kurikulum pelatihan Dasar Pekerti untuk dosen yang diselenggarakan Akademi Pariwisara CBI Sukabumi difokuskan ke pada penguasaan materi kompetensi Higher Order untuk tiga macam kompetensi yakni Cognitave, Affective, dan Psychomotor.

B. Higher Order untuk Cognitave disebut Hots yang meliputi C4,C5,C6, Higher Order untuk Affective disebut H.O Affective yang meliputi A4,A5, Higher Order untuk Psychomotor disebut H.O Psychomotor yang meliputi P4,P5.

C. Proses pelaksanaan pelatihan kompetensi Higher Order harus tetsusun secara sistematis, berurut : memahami Hots dan H.O, memahami integrasi Hots/ H.O serta contoh penerapannya, mengukur komposisi kompetensi Higher Order serta metode pembelajaran yang berkesuaian, serta mengassesmen untuk mencapai Goals.

D. Goals pembelajaran Higher Order meliputi rumusan tentang kemampuan problem solving, kinerja, produk abstrak, produk real. Kualifikasi goals terhadap rumusan merupakan strata : sudah menghasilkan/output, hasil yang bermanfaat dan berkualitas/outcomes, hasil yang berdampak/impact.

\section{DAFTAR PUSAKA}

Anderson, L.W. and D.R Krathwohl, 2001,A Taxonomy for learning, teaching, andassessing, A revision on Bloom's Taxonomy of educational objectives, New York, Longman.

Direktorat Jenderal Pendidikan Tinggi Kemdikbud RI, Buku Panduan Merdeka Belajar, Edisi 1 tahun 2020 
Hapson, M.H.,Simms,R.L.,\& Knezek, G.A. (2001).Using a Technology Enriched environment to improve higher orfer thinking skills, Journal of Research on Technology of Education, Winter 2001-2002: Vol 34, 2, 109-119 Retrieved from https;// www.isteorg/Learn/Publication/Journals/jrt e

Hammond,G.(n.d).Higher Order Thinking, Retrieved June 2010. Fromhttp://xnet.rrc.mb.ca/Glenh/h ots.htm.

King, F. J, Goodson, L, Rohani, F 2004. Hiigher Order Thinking skill, A publication of The

Educational Service Program. Now known us the center for advancement of Learning and Assessment.

Menilai Dengan Rubrik, Jenis Jenis Rubrik, Google, 2018

Pengembangan RPS, FBS-UNY, christina Ismaniati, yogyakarta, 2018

Pengertian Deskriptif, Sugiono dalam Pengertian Penelitian Deskriptif, Google, 8 Juli 2020.

Ristek Dikti, Syamsul Arifin, Desain pembelajaran dan Penyusunan RPS Pendidikan Tinggi, Jakarta, 2019

Stiggins,R.J., Rubel,E., and Quellmalz,E.1998) Measuring thinking Skills in the classroom. ( Revised E.d). Washington, DC : National Education Association

Wilks,S. (1995) , Critical and Creative

Thinking strategy for classroom inquiry. Armidale, NSW: Elanor Curtain

Zoller, U., Ben-Chaim, D., Ron, S.,
Pentimalli, R., \& Borsese, A, ( 2000) The disposition toward critical thinking of High school and university Students; an inter-intra Israel-Italia Study . International Jornals of Science Education 22( 6), 571-582 